To Maega $\mid$ Jurnal Pengabdian Masyarakat

Bulan-Tahun, Vol. 3, No. 2, hal. 74-82

$\operatorname{ISSN}(P): 2622-6332 ; \operatorname{ISSN}(E): 2622-6340$

http://www.ojs.unanda.ac.id/index.php/tomaega

\title{
Edukasi Kesehatan Dalam Upaya Pencegahan dan Pengendalian Penyakit Hipertensi Pada Lansia
}

\author{
Rea Ariyanti1,a, ${ }^{*}$, Ida Ayu Preharsini2,b, Berliany Venny Sipolio ${ }^{3, c}$ \\ ${ }_{1}^{1}$ Program Studi DIV MIK, STIKes Panti Waluya Malang \\ ${ }^{2}$ Program Studi S1 Farmasi, STIKes Panti Waluya Malang \\ ${ }^{3}$ Program Studi S1 Keperawatan, STIKes Panti Waluya Malang \\ a,b,cEmail:ariantirea@gmail.com; preharsinik@gmail.com; berlianyvenny@rocketmail.com \\ ${ }^{*}$ Correspondent Email: ariantirea@gmail.com
}

Article History:

Received: 13-06-2020; Received in Revised: 23-06-2020; Accepted: 07-07-2020

DOI: http://dx.doi.org/10.35914/tomaega.v3i2.369

\begin{abstract}
Abstrak
Lansia (lanjut usia) adalah seseorang yang berusia 60 tahun keatas. Lansia dikatakan memiliki risiko untuk mengalami berbagai penyakit degeneratif dibandingkan dengan usia muda. Salah satu penyakit degeneratif yang sering timbul tanpa gejala adalah hipertensi. Hipertensi disebut sebagai "silent killer" karena bisa muncul tanpa gejala atau tanda-tanda peringatan, sehingga banyak yang tidak menyadarinya. Penyebab terlambatnya penanganan pada pasien dengan hipertensi adalah mayoritas pasien datang ke fasilitas kesehatan apabila telah terjadi komplikasi, dan kurangnya akses masyarakat terhadap pelayanan kesehatan sehingga mengakibatkan kurangnya kontrol terhadap keadaan penyakitnya khususnya pada lansia. Oleh karena itu, dengan dilakukannya pemberdayaan kader terkait hipertensi diharapkan peran kader dalam upaya pencegahan dan pengendalian hipertensi pada lansia dapat berjalan optimal. Program kemitraan ini bertujuan untuk meningkatkan pemahaman kader terhadap upaya pencegahan dan pengendalian hipertensi pada lansia. Target utama program ini adalah kader kesehatan di Dusun Sukosari, Desa Pandansari, Kecamatan Poncokusumo, Kabupaten Malang. Kegiatan ini meliputi survei awal terkait hipertensi pada Lansia, dan melaksanakan penyuluhan tentang upaya pencegahan dan pengendalian hipertensi pada lansia dengan menggunakan metode penyuluhan dan diskusi interaktif. Hasil dari kegiatan pengabdian masyarakat ini adalah adanya peningkatan pemahaman kader kesehatan terkait Penyakit Hipertensi khususnya upaya dalam pencegahan dan pengendalian penyakit hipertensi pada lansia di Dusun Sukosari, Desa Pandansari, Kecamatan Poncokusumo, Kabupaten Malang.
\end{abstract}

Kata Kunci: Degeneratif, Hipertensi, Lansia

\begin{abstract}
Lansia is someone who is at the age of 60 years and above. lansia Elderly have the risk to experience a variety of degenerative diseases compared with young age. One of the many degenerative diseases that often arise without symptoms is hypertension. Hypertension is referred to as "silent killer" because it can appear without any symptoms or warning signs, so many do not realize it. Due to the delay of treatment in patients with hypertension is the majority of patients come to health facilities when there have been complications, and because of lack of public access to health services, resulting in lack of control of the condition of illness especially in the elderly. Therefore, the empowerment of
\end{abstract}


cadres related to hypertension is expected the role of cadres in the prevention and control of hypertension in the elderly can run optimally. This Program aims to improve cadre's understanding of prevention and control of hypertension in the elderly. The main target of this program is elderly cadres in Sukosari Hamlet, Pandansari Village, Poncokusumo District, Malang Regency. This activity includes preliminary surveys related to hypertension in the elderly, and further conducting counseling on prevention and control of hypertension in the elderly. The result of this activity is the increase in understanding health cadres related to hypertension, especially efforts in the prevention and control of hypertension disease in the elderly in Sukosari Hamlet, Pandansari Village, sub-district Poncokusumo, Malang.

Key Word: Degenerative, Elderly, Hypertension.

\section{Pendahuluan}

Lansia atau lanjut usia adalah seseorang yang berusia 60 tahun keatas (Kemenkes RI, 2019). Lansia lebih memiliki risiko atau memungkinkan untuk mengalami berbagai penyakit khususnya penyakit degeneratif jika dibandingkan dengan usia muda. Penyakit degeneratif merupakan penyakit kronik menahun yang banyak mempengaruhi kualitas hidup serta produktivitas seseorang (Nisak; Maimunah; Admadi, 2018). Salah satu penyakit degeneratif pada lansia yang sering timbul tanpa gejala adalah hipertensi (Kholifah, 2016).

Hipertensi merupakan penyebab kematian dini di seluruh dunia yang sebenarnya dapat dicegah (Katherina; Joshua; Tanika, et al, 2016). Di Indonesia, Hipertensi merupakan salah satu penyebab utama mortalitas dan morbiditas, sehingga tatalaksana penyakit ini merupakan intervensi yang sangat umum dilakukan di berbagai tingkat fasilitas kesehatan (Perhimpunan Dokter Speasialis Kardiovaskular Indonesia, 2015). Penyakit hipertensi sering disebut sebagai "silent killer" karena bisa muncul tanpa gejala atau tanda-tanda peringatan, sehingga banyak yang tidak menyadarinya (Brunner dan Suddarth, 2013). Kondisi demikian menjadi salah satu penyebab terlambat nya penanganan pada pasien dengan hipertensi, karena mayoritas pasien datang ke fasilitas kesehatan apabila telah terjadi komplikasi akibat penyakit hipertensi. Selain itu, kurang nya akses masyarakat terhadap pelayanan kesehatan juga menyebab kan kurangnya kontrol terhadap keadaan penyakitnya khususnya pada lansia.

Peningkatan prevalensi penyakit tidak menular menjadi ancaman yang serius dalam pembangunan, karena mengancam pertumbuhan ekonomi nasional. Oleh karena itu, dikembangan model pengendalian PTM berbasis masyarakat melalui Posbindu PTM. Posbindu PTM merupakan bentuk peran serta masyarakat dalam upaya pengendalian faktor risiko secara mandiri dan berkesinambungan (Kementerian Kesehatan RI, 2012). Posyandu PTM merupakan salah satu bentuk pemberdayaan masyarakat yang dapat menjembatani antara tenaga kesehatan dengan masyarakat. 
Kader Posyandu PTM merupakan jajaran pertama dalam menjangkau masyarakat, ketika tenaga kesehatan tidak ada atau ketika masyarakat sulit mendapatkan akses ke tenaga kesehatan. Kader kesehatan dapat menjadi perpanjangan tangan dalam meningkatkan pemahaman masyarakat tentang status kesehatan nya. Selain itu, kader posyandu PTM juga merupakan jajaran terdepan dalam mentransfer pengetahuan, pemahaman dan keterampilan dalam menangani berbagai macam penyakit degeneratif khususnya hipertensi, sehingga kader menjadi sangat penting untuk mendapatkan pemahaman tentang penyakit hipertensi itu sendiri dan berkenaan dengan upaya pencegahan dan pengendalian penyakit hipertensi khususnya pada lansia.

Desa Pandansari merupakan salah satu desa yang terletak di Kecamatan Poncokusumo, Kabupaten Malang. Secara geografis, desa Pandansari terletak di lereng gunung Semeru dan gunung Bromo yang merupakan gugusan gunung aktif di wilayah provinsi Jawa Timur. Desa Pandansari berbatasan langsung dengan Perhutani pada sisi Timur, desa Sumberejo pada sisi Selatan, dan desa Ngadireso pada sisi Barat. Desa Pandansari terdiri dari tiga dusun, yaitu Dusun Pandansari Krajan, Dusun Wonosari, dan Dusun Sukosari.

Jumlah penduduk di desa Pandansari berjumlah 7000 jiwa, dengan rincian 3.644 jiwa laki-laki, dan 3.356 jiwa perempuan. Pendidikan akhir yang dimiliki penduduk di Desa Pandansari bervariasi. Mayoritas pendidikan formal yang ditempuh oleh penduduk di Desa Pandansari adalah Sekolah Dasar (SD) sebanyak 3.752 jiwa, berpendidikan SLTP sebanyak 676 jiwa, berpendidikan SLTA sebanyak 152 jiwa, lulus sarjana sebanyak 51 jiwa, dan sisanya atau sebanyak 762 jiwa tidak pernah menempuh pendidikan formal. Menurut Penelitian yang dilakukan oleh Putri (2017) menunjukkan bahwa ada hubungan yang signifikan antara tingkat pendidikan responden dengan pengetahuan (Putri, 2017).

Desa Pandansari rutin menghadapi kejadian tanah longsor, banjir, dan puting beliung setiap tahunnya, termasuk munculnya retakan pada rumah warga akibat pergeseran tanah. Kontur tanah di desa Pandansari cenderung berbukit dengan komposisi tanah berpasir. Tanah berpasir menimbulkan permasalahan tersendiri, yaitu tanah longsor yang terjadi baik saat musim penghujan maupun kemarau. Tanah longsor akan memutuskan akses jalan dari desa Pandansari ke arah Poncokusumo. Hal ini akan berdampak pada kesehatan masyarakat. Saat terjadi tanah longsor, akses jalan akan tertutup sehingga masyarakat sulit untuk mencari fasilitas pelayanan kesehatan.

Akses menuju tenaga kesehatan atau fasilitas kesehatan tidak terlalu menjadi masalah bagi penduduk dusun Pandansari Krajan karena perawat desa dan bidan terletak pada dusun ini. Namun akses kepada tenaga kesehatan akan lebih sulit didapat bagi penduduk dusun Sukosari. Hal ini disebabkan karena lokasi dusun Sukosari yang terletak lebih jauh jika dibandingkan dengan dua 
dusun lainnya. Jalan yang naik turun dan sempit karena terletak di area perbukitan mempersulit warga untuk mendapat pelayanan kesehatan. Dua RT pada dusun Sukosari letaknya cukup jauh dari lima RT lainnya dalam satu desa, kedua RT tersebut juga dilalui oleh sungai musiman. Sehingga pada saat sungai meluap dimusim penghujan, masyarakat kedua RT akan terisolir dari lokasi lainnya. Kondisi ini tentu saja akan menyulitkan penduduk untuk mendapatkan akses ke tenaga kesehatan atau fasilitas pelayanan kesehatan terutama pada lansia.

Program kemitraan ini bertujuan untuk meningkatkan pemahaman kader terkait penyakit hipertensi khususnya dalam upaya pencegahan dan pengendalian penyakit hipertensi pada lansia. Dengan adanya pemberdayaan kepada kader kesehatan di dusun Sukosari terkait pencegahan dan pengendalian penyakit hipertensi diharapkan pemahaman kader kesehatan terkait upaya pencegahan dan pengendalian penyakit hipertensi dapat meningkat sehingga mampu ikut berperan dalam mencegah dan menurunkan prevalensi penyakit hipertensi pada lansia di Dusun Sukosari, Desa Pandansari, Kecamatan Poncokusumo, Kabupaten Malang.

\section{Metode}

Metode pelaksanaan yang diterapkan untuk mencapai tujuan dari program kemitraan ini adalah dengan melakukan penyuluhan dan diskusi interaktif. Penyuluhan diberikan oleh 3 pemateri kepada 15 kader kesehatan yang ada di Dusun Sukosari dengan masing-masing diberikan waktu 45 menit. Kegiatan dilaksanakan pada pagi hari pukul 10.00 WIB sampai dengan 13.00 WIB. Adapun materi yang diberikan adalah materi terkait penyakit hipertensi, upaya pencegahan penyakit hipertensi pada lansia dan upaya pengendalian penyakit hipertensi pada lansia. Selain memaparkan materi yang diberikan pada saat penyuluhan, pemateri juga membagikan media bantu seperti leaflet hipertensi pada lansia kepada para kader.

Kegiatan ini dilakukan untuk meningkatkan pemahaman kader terkait upaya pencegahan dan pengendalian penyakit hipertensi pada lansia. Untuk menilai tingkat pemahaman kader terkait penyakit hipertensi khususnya upaya pencegahan dan pengendalian penyakit hipertensi pada lansia, maka sebelum diberikan penyuluhan, para kader akan dilakukan pretest dan di akhir penyuluhan akan dilakukan posttest. Secara garis besar, pertanyaan yang dicantumkan pada pre dan posttest adalah pertanyaan seputar hipertensi seperti definisi hipertensi, faktor risiko hipertensi, penyebab hipertensi, dampak hipertensi, upaya pencegahan hipertensi, dan upaya pengendalian hipertensi. 


\section{Hasil dan Pembahasan}

\section{A. Tahap Pra Kegiatan}

Program Kemitraan yang dilaksanakan di Dusun Sukosari, Desa Pandansari, Kecamatan Poncokusumo, Kabupaten Malang ini mendapat kan respon yang positif dari Puskesmas Poncokusumo dan Perangkat Desa Pandansari, Khususnya Para Kader Kesehatan di Dusun Sukosari. Sasaran utama program ini adalah kader kesehatan yang ada di Dusun Sukosari, Ds.Pandansari, Kec. Poncokusumo, Kabupaten Malang. Pra kegiatan ini dilaksanakan pada tanggal 4 Januari 2020 bersamaan dengan dilaksanakannya Posyandu Lansia.
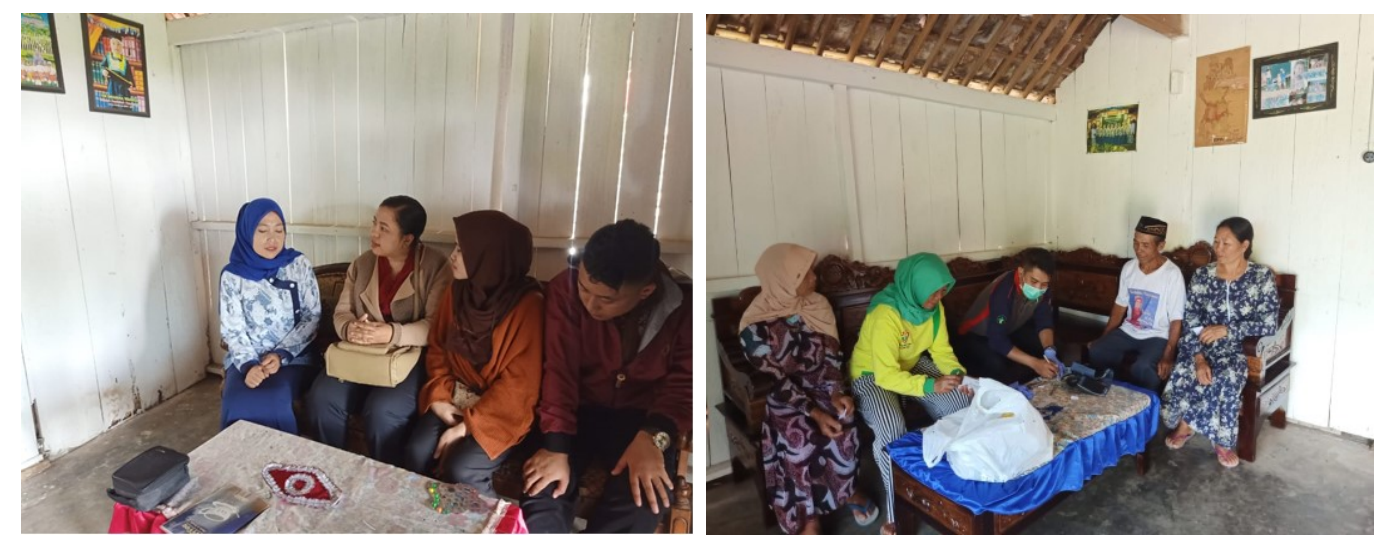

Gambar 1. Tahap Pra Kegiatan

Pra kegiatan yang dilakukan adalah melakukan koordinasi kepada perwakilan kader kesehatan, diskusi terkait hipertensi pada lansia dan melakukan sosialisasi kegiatan penyuluhan kepada para kader di Dusun Sukosari yang berjumlah 15 orang. Dari hasil diskusi oleh salah satu kader yang ada di Dusun Sukosari, diketahui bahwa masih banyaknya lansia di Dusun Sukosari yang menderita hipertensi, bahkan tekanan darahnya ada yang mencapai $250 \mathrm{mmHg}$ untuk sistoliknya. Berdasarkan hal tersebut, maka disepakati bahwa perlunya ada sosialisasi kepada kader terkait upaya pencegahan dan pengendalian penyakit hipertensi kepada para kader lansia di Dusun Sukosari.

\section{B. Tahap Pelaksanaan Kegiatan}

Pelaksanaan kegiatan penyuluhan dilaksanakan sebanyak 2 (dua) kali yaitu pada tanggal 11 dan 18 Januari 2020 di Posyandu Lansia dengan metode ceramah dan diskusi inetraktif bersama dengan 15 kader kesehatan lansia. Kegiatan Penyuluhan I disampaikan oleh 2 pemateri yaitu Dosen dari Program Studi D-IV Manajemen Informasi Kesehatan dan S1 Keperawatan dengan rincian materi sebagai berikut: Penyakit hipertensi dan upaya pencegahan penyakit hipertensi pada lansia, dan upaya pengendalian penyakit hipertensi pada lansia. Sedangkan, kegiatan penyuluhan II disampaikan oleh 1 pemateri dari dosen Prodi S1 Farmasi dengan materi Terapi Farmakologi dan Non Farmakologi Penyakit Hipertensi. 

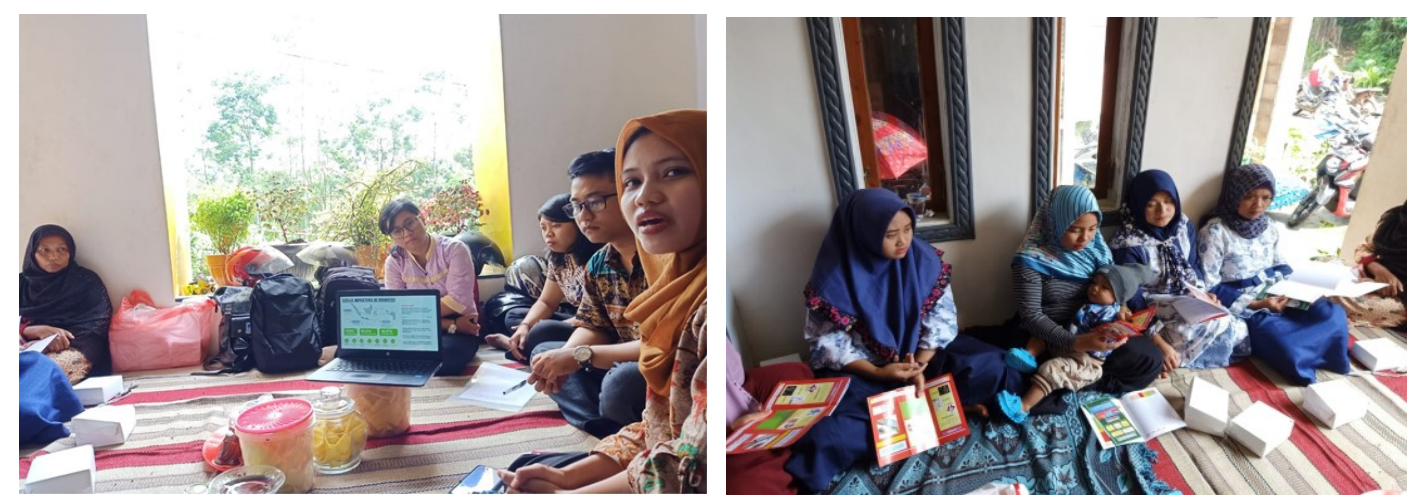

Gambar 2. Tahap Pelaksanaan Kegiatan

Penyampaian materi terapi non farmakologi penyakit hipertensi diberikan karena sebagian besar guideline hipertensi merekomendasi kan tatalaksana farmakologi pada pasien dengan tekanan darah 140/90 $\mathrm{mmHg}$ yang belum mencapai target TD yang diinginkan dengan melakukan modifikasi gaya hidup (Kandarini, 2016). Intervensi hipertensi berupa modifikasi gaya hidup dapat menghambat progresivitas hipertensi. Namun, sebagian besar pasien memerlukan obat anti hipertensi seumur hidup dengan kombinasi lebih dari satu obat. Oleh karena itu, disepakati untuk memberikan materi terkait terapi farmakologi dan non farmakologi penyakit hipertensi.

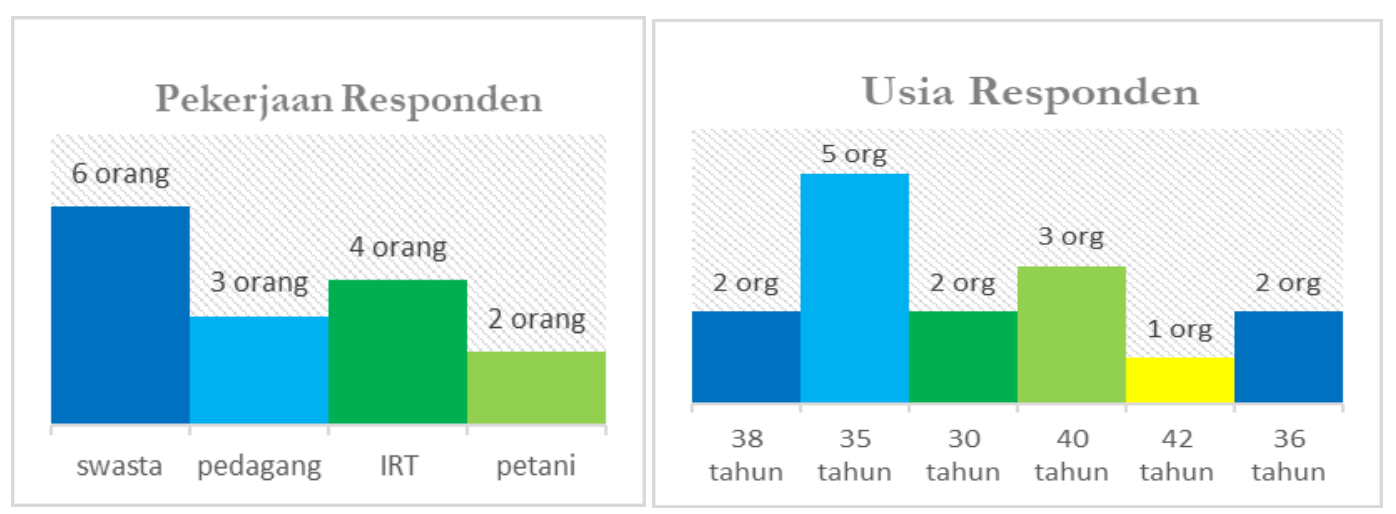

Gambar 3. Distribusi Frekuensi Pekerjaan dan Usia Responden

Berdasarkan hasil analisa distribusi pekerjaan responden, mayoritas responden bekerja sebagai pegawai swasta yaitu 6 orang dan berusia 35 orang yaitu 5 orang. Sebelum dilaksanakan kegiatan penyuluhan, terlebih dahulu dilakukan pretest guna menilai tingkat pemahaman para kader kesehatan lansia dalam upaya pencegahan dan pengendalian penyakit hipertensi pada lansia dan setelah dilaksanakan kegiatan penyuluhan, dilakukan kembali postest guna menilai adanya peningkatan pemahaman atau tidak pada kader kesehatan terkait upaya pencegahan dan pengendalian penyakit hipertensi pada lansia. Antusiasme kader kesehatan lansia di Dusun Sukosari ini sangat tinggi. Hal ini ditunjukkan dengan keaktifan para kader kesehatan pada saat dilakukan penyuluhan dan saat diskusi. 


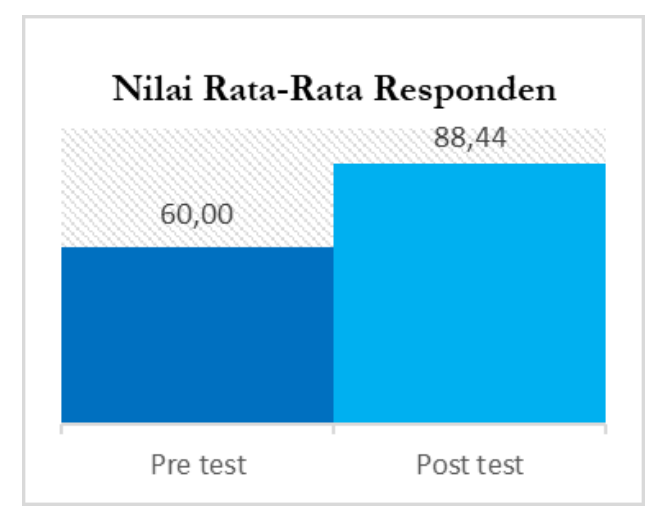

Gambar 4. Nilai Pre test dan Post test

Dari hasil analisa data yang dilakukan pada nilai pretest dan postest para kader kesehatan, diketahui bahwa telah terjadi peningkatan atau kenaikan tingkat pemahaman terkait upaya pencegahan dan pengendalian penyakit hipertensi pada lansia, hal ini dapat dilihat pada Tabel 1, dimana sebelum diberikan penyuluhan, rata-rata nilai pre test sebesar 60,00 dan setelah diberikan penyuluhan terjadi peningkatan nilai post test menjadi 88,44 . Hasil kegiatan ini juga sesuai dengan penelitian sebelumnya yang dilakukan oleh Sofiana dkk (2018) yang menunjukkan bahwa terdapat perbedaan bermakna antara tingkat pengetahuan akhir dengan tingkat pengetahuan awal pada responden yang telah mendapatkan penyuluhan. Penyuluhan kesehatan dapat mempengaruhi perubahan perilaku responden karena adanya perubahan pengetahuan. Dengan diberikannya penyuluhan, maka responden yang semula belum mengetahui menjadi mengetahui dan memahami (Muthia, 2016).

\section{Kesimpulan}

Kegiatan Pengabdian Kepada Masyarakat yang dilaksanakan di Dusun Sukosari, Desa Pandansari, Kecamatan Poncokusumo, Kabupaten Malang terlaksana sesuai dengan rencana yang telah disusun, meliputi pemberian edukasi dengan metode ceramah dan diskusi interaktif pada 15 kader kesehatan yang ada di dusun Sukosari. Edukasi kesehatan pada kader kesehatan di Dusun Sukosari, Desa Pandansari, Kecamatan Poncokusumo, Kabupaten Malang mengenai pentingnya pencegahan penyakit hipertensi menunjukkan adanya peningkatan pemahaman para kader kesehatan terkait hipertensi pada lansia, termasuk didalamnya adalah bagaimana melakukan upaya pencegahan dan pengendalian penyakit hipertensi khususnya pada lansia.

Dari hasil kegiatan ini, saran yang dapat penulis berikan adalah (1) bagi pelayanan kesehatan, khususnya posyandu lansia diharapkan dapat berperan dalam memberikan pelayanan pemeriksaan kesehatan, dan menjadi edukator dalam memberikan informasi atau penyuluhan tentang hipertensi kepada lanisa 
ataupun keluarga lansia, terutama terkait pola makan, aktifitas fisik, rutin kontrol kesehatan, dan manajemen pengelolaan stress; dan (2) Bagi keluarga lansia, diharapkan dapat selalu memperhatikan tentang status kesehatan individu didalam keluarga terutama pada lansia, memberikan dukungan untuk rutin memeriksakan diri ke fasilitas pelayanan kesehatan.

\section{Ucapan Terimakasih}

Terima kasih penulis sampaikan kepada STIKes Panti Waluya Malang yang telah bersedia untuk mendanai kegiatan pengabdian kepada masyarakat ini hingga selesai.

\section{Daftar Pustaka}

Brunner, Suddarth. (2013). Buku Ajar Keperawatan Medikal Bedah Edisi 8. Vol 2. Jakarta: EGC

InaSH. (2014). Konsensus Penatalaksanaan Hipertensi 2014. Perhimpunan Dokter Hipertensi Indonesia. Jakarta.

James, PA., Oparil,S., Cushman,WC., Dennison, HC., Handler, J., dkk. (2014). Evidence-Based Guideline for the Management of High Blood Pressure in Adults: Report Form the Panel Members Appointed to the Eight Joint National Committee (JNC 8). JAMA. 311(5): 507-20.

Kandarini, Y. (2016). Tatalaksana Farmakologi Terapi Hipertensi. Denpasar: FK Universitas Udayana

Katherine, TM., Joshua, DB., Tanika, NK., et al. (2016). Global Disparities of Hypertension Prevalence and Control. Circulation American Heart Association (AHA).

Kementerian Kesehatan RI. (2012). Petunjuk Teknis Pos Pembinaan Terpadu Penyakit Tidak Menular (POSBINDU PTM). Jakarta: Direktorat Pengendalian Penyakit Tidak Menular.

Kementerian Kesehatan RI. (2019). Situasi Lanjut Usia (LANSIA) di Indonesia. Jakarta: Pusat Data dan Informasi Kementerian Kesehatan RI.

Kholifah, S (2016). Keperawatan Gerontik. Jakarta: Kementerian Keseharan Republik Indonesia: Pusat Pendidikan Sumber Daya Manusia Kesehatan Badang Pengembangan dan Pemberdayaan Sumber Daya Manusia Kesehatan.

Muthia, F., Fitriangga, A. (2016). Perbedaan Efektifitas Penyuluhan Kesehatan menggunakan Metode Ceramah dan Media Audiovisual (Film) terhadap Pengetahuan Santri Madrasah Aliyah Pesantren Khulafaur Rasyidin. Jurnal Cerebellum, 2(4), 646-656.

Nisak R, Maimunah S, Admadi T. (2018). Upaya Pemberdayaan Masyarakat Melalui Deteksi Dini Pengendalian Penyakit Degeneratif pada Lansia di Dusun Karang Pucang, Desa Ngancar, Kecamatan Pitu, Wilayah Kerja

(C)To Maega / Jurnal Pengabdian Masyarakat. This is an open access article under the CC BY-SA 4.0 license (https://creativecommons.org/licenses/by-sa/4.0/). 
[ 82 ] Rea Ariyanti, dkk / To Maega : Jurnal Pengabdian Masyarakat, Vol.3; No.2, Agustus 2020

Puskesmas Pitu, Kabupaten Ngawi. Ngawi: Akademi Keperawatan Pemerintah Kabupaten Ngawi

Perhimpunan Dokter Spesialis Kardiovaskular Indonesia (2015). Pedoman Tatalaksana Hipertensi pada Penyakit Kardiovaskular. Perhimpunan Dokter Spesialis Kardiovaskular Indonesia

Putri, R. (2017). Hubungan Antara Tingkat Pendidikan dan Tingkat Pengetahuan dengan Perilaku Hidup Sehat Kualitas Lingkungan Rumah. Studi Masayarakat Kabupaten Pringsewu, Kelurahan Pringsewu Barat. Bandar Lampung: Universitas Lampung

Sofiana L., Puratmadja Y., Kartika SBK., Pangulu AHR, Putri IH. (2018). Upaya Peningkatan Pengetahuan Tentang Hipertensi Melalui Metode Penyuluhan. Jurnal Pemberdayaan: Publikasi Hasil Pengabdian Kepada Masyarakat. 2(1) : 171-176. 